Original article

Section: Food Quality and Functionality

\title{
Effect of Enzyme-Assisted Vinification on Wine Phenolics, Colour Components, and Antioxidant Capacity
}

\author{
Ivana Generalić Mekinić1*, Živko Skračič ${ }^{2}$, Ana Kokeza ${ }^{1}$, Barbara Soldo’3, \\ Ivica Ljubenkov ${ }^{3}$, Mara Banović, ${ }^{4}$ Vida Šimat ${ }^{5}$, Danijela Skroza ${ }^{1}$
}

\author{
${ }^{1}$ Department of Food Technology and Biotechnology, Faculty of Chemistry and Technology, University of Split, \\ R. Boškovića 35, HR-21000 Split, Croatia \\ ${ }_{2}^{2}$ Secondary School "Braća Radić, Put poljoprivrednika bb, HR-21217 Kaštel Štafilić, Croatia \\ ${ }^{3}$ Department of Chemistry, Faculty of Science, University of Split, R. Boškovica 33, HR-21000 Split, Croatia \\ ${ }^{4}$ Department of Food Engineering, Faculty of Food Technology and Biotechnology, University of Zagreb, \\ Pierottijeva 6, HR-10000 Zagreb, Croatia \\ ${ }^{5}$ University Department of Marine Studies, University of Split, R. Boškovića 37, HR-21000 Split, Croatia
}

Key words: Babica $c$., winemaking, enzyme-assisted vinification, phenolic compounds, colour, antioxidant activity

The aim of this study was to evaluate the impact of the macerating enzyme addition (Sihazym Extro and Vinozym Vintage) on the extraction of phenolics, colour components, and antioxidants in Babica wine. Spectrophotometry was used for determination of total phenolics, anthocyanins, and wine colour parameters (intensity, hue, and chromatic structure); the individual phenolics were detected using HPLC; while reducing and free radical scavenging activities of the samples were analysed using the FRAP and DPPH assays. The results indicate a more favourable effect of the Sihazym Extro on the extraction of phenolics, while both enzymes improved the extraction of anthocyanins during the maceration. The most abundant phenolic compounds were malvidin derivatives whose concentration continuously increased during the vinification and reached $82 \%$ of all anthocyanin derivatives in the control wine and $81 \%$ in both enzyme-treated wines. As expected, the antioxidant activity of the samples followed the trend of phenolics content growth and increased during the vinification, resulting in the higher activity of the enzyme-treated wines.

\section{INTRODUCTION}

Despite the devastation of natural potentials and strong deagrarization, the grape vine cultivation and wine production in Dalmatia has subsisted through the centuries. The representations of the individual grape varieties have changed significantly, but most of the indigenous species remained preserved. In the region of Central Dalmatia, especially in the coastal area from Kaštela to Trogir, Babica is the most abundant red grape cultivar. For a long time it was considered as synonym for the well-known Croatian red grape variety Babić, however, ampelographic and genetic identifications confirmed that Babica and Babić are two completely different varieties and that Babica is the direct descendant of the Plavac mali variety [Maletić et al., 2009; Zdunić et al., 2008]. According to the recent data, this grape cultivar occupies an area of approximately 18.5 ha, mostly in Kaštela-Trogir vineyards [Maletić et al., 2015], where, due to its good features and resistance to the diseases, it is a leading grape variety for the production of different types of wine [Ozimec et al., 2015].

\footnotetext{
* Corresponding Author: Tel.: +385 21329 458;

E-mail: gene@ktf-split.hr (I. Generalić Mekinić)
}

Wine colour is an important element of wine quality and one of the most important features that influence its commercial acceptance. The compounds responsible for red wine colour and flavour are anthocyanins, that are accumulated in the grape skin, and their extraction during the maceration is an essential step during red wine production. In the traditional winemaking, during the classic maceration, only about $40 \%$ of total anthocyanins are extracted from the skins [El Darra et al., 2016], the maximal concentration is reached between 3 and 8 day of maceration and afterwards a slight decrease of anthocyanins could be noted [Ortega-Regules et al., 2006; Rio Segade et al., 2015; Romero-Cascales et al., 2012; Sacchi et al., 2005].

Today, the imperative of winemaking industry is the production of wines with a high biological value, expressed colour intensity, and improved stability during the aging so the addition of pectolytic enzymes often plays a fundamental role as their use offers quantitative (higher juice yield), qualitative (improved extraction and better organoleptic properties, colour stability during the wine aging, maturation and storage), and processing benefits (e.g. shorter maceration, filtration) [Claus \& Mojsov, 2018; Kelebek et al., 2007; Mihnea et al., 2015; Mojsov, 2013; Romero-Cascales et al., 
2012]. The concentration of monomeric anthocyanins in red wines during the maturation declines constantly as a result of different mechanisms such as their adsorption by yeast, degradation and oxidation, precipitation with proteins, polysaccharides and/or condensed tannins, and the irreversible formation of more complex (oligomeric and polimeric) pigments which are crucial for colour stability [Boulton, 2001; He et al., 2012]. All these reactions are responsible for colour changes from the deep-purple colour of the young wines (due to presence of monomeric anthocyanins and reactions of self-association co-pigmentation), to the orange and brick-red tones as the wine ages [Marquez et al., 2013].

Numerous studies have been carried out into the effect of various pre-fermentative oenological practices on the yield and profile of extracted red wine phenolics, and the reported results are often contradictory. The results of our recent study on Crljenak kaštelanski variety [Generalić Mekinić et al., 2019] showed that the highest yield of phenolics was detected in wine produced without enzyme addition; no significant increase was reported in the study of El Darra et al. [2016], while studies of Pardo et al. [1999], Kelebek et al. [2007], and Romero-Cascales et al. [2012] reported a better extraction yield of phenolics by the use of enzyme preparations. In turn, Pardo et al. [1999], Kelebek et al. [2007], Mojsov et al. [2010], Bichescu et al. [2012], and Rio Segade et al. [2015] detected a higher content of anthocyanins in enzyme-treated wines, and regarding the wine chromatic and sensory characteristics Bautista-Ortin et al. [2005] reported opposite effects of two enzyme preparations, while Pardo et al. [1999], Kelebek et al. [2007], Soto-Vazquez et al. [2010], Bichescu et al. [2012], and Romero-Cascales et al. [2012] confirmed the positive effect of enzymes on these wine parameters.

The aim of this study was to evaluate the effect of pectolytic enzyme addition during winemaking of Babica cv. on the extraction and evolution of wine phenolic compounds, colour components, and antioxidants in order to draw conclusions on choosing the optimal procedure for the production of highly-coloured red wine rich in biologically active compounds.

\section{MATERIALS AND METHODS}

\section{Chemicals and reagents}

All standards, reagents, and solvents used in this research were of adequate analytical grade and were purchased from Kemika (Zagreb, Croatia), Alkaloid AD (Skopje, Macedonia), BDH Chemicals (London, UK), Fluka (Buchs, Germany), and Sigma-Aldrich (Steinheim, Germany).

\section{Grape samples and vinification}

The raw materials were hand-picked grapes from Vitis vinifera var. Babica (from the vineyard located in Kaštela, Croatia). After the harvest, about $100 \mathrm{~kg}$ of grapes for each experiment were transported to winery and processed as follows: a) by the traditional winemaking procedure (control sample), and by two procedures using enzymes ( $3 \mathrm{~g} / 100 \mathrm{~L})$; b) Vinozym Vintage ${ }^{\circledR}$ FCE (Novozymes A/S, Bagsvaerd, Denmark), and c) Sihazym Extro (Eaton Begerow Product Line, Langenlonsheim, Germany), respectively. The vinification procedure and sampling protocol were previously described by Generalić Mekinić et al. [2019]. Weighed and destemmed grapes were crushed with an MGM- 940 crusher (MIO, Osijek, Croatia) and pectolytic enzyme preparations were added to fermentation tanks. The prepared mashes were treated with potassium metabisulphite $(10 \mathrm{~g} / 100 \mathrm{~L})$ and inoculated $(15 \mathrm{~g} / 100 \mathrm{~L})$ (SIHA®, Aktiv Hefe 8, Burgundy Yeast, E. Begerrow GmbH \& Co., Langenlonsheim, Germany). The maceration time was 5 days (at $\sim 25$ to $27^{\circ} \mathrm{C}$ ), and the cap of grape solid was kept soaked using the mechanical barrier. After maceration, free run wine and the pressed wine were combined, and the pomace was removed. The produced wine was sealed with the tank's floating lid and paraffin oil. The dynamics of the extraction was monitored daily during the maceration and after the racking (approximately 40 and 160 days after the winemaking process started).

\section{Phenolic compounds and wine colour parameters}

Spectrophotometric measurements were performed on a Specord 200 spectrophotometer (Analytik Jena GmbH, Jena, Germany).

The total phenolics content in the samples was determined by the colorimetric Folin-Ciocalteu method [Singleton \& Rossi, 1965] and the results are expressed as mg of gallic acid equivalents per litre (mg GAE/L).

The monomeric anthocyanins content was determined using the assay described originally by Amerine \& Ough [1980]. The obtained results are expressed as mg of malvidin 3-O-glucoside equivalents per litre (mg M-3-gl/L).

Wine colour parameters as intensity $(\mathrm{CI})$, hue $(\mathrm{T})$, and the percentages of yellow (OD $420=\mathrm{A} 420 / \mathrm{CI} \times 100)$, red $(\mathrm{OD} 520=\mathrm{A} 520 / \mathrm{CI} \times 100)$, and blue $(\mathrm{OD} 620=\mathrm{A} 620$ $/ \mathrm{CI} \times 100)$ were measured and calculated according to Alpeza et al. [2017].

\section{HPLC analysis}

The individual phenolic compounds were detected using a high-performance liquid chromatography (HPLC) system consisting of an autosampler, a binary pump, a vacuum degasser, a UV/VIS detector, and the Peltier column oven (all of Series 200) (Perkin Elmer, Walthamn, MA, USA). Separation, identification, and quantification of phenolic acids, flavonoids, and stilbene were performed on an UltraAqueous C18 column $(250 \times 4.6 \mathrm{~mm}, 5 \mu \mathrm{m}$, Restek, Bellefonte, PA, USA) while the analysis of anthocyanins was performed on the Kinetex core-shell C18 column $(150 \times 4.6 \mathrm{~mm}, 5 \mu \mathrm{m}$, Phenomenex, Torrance, CA, USA).

Separation, identification, and quantification of the individual phenolics were performed by HPLC methods as described by Generalić Mekinić et al. [2019] using 0.2\% phosphoric acid in water (solvent A) and 50\% acetonitrile in methanol (solvent B). A gradient was applied as follows: from $96 \%$ A at $0 \mathrm{~min}$ to $50 \% \mathrm{~A}$ at $40 \mathrm{~min}$, to $40 \% \mathrm{~A}$ at $45 \mathrm{~min}$, to $20 \% \mathrm{~A}$ at $50 \mathrm{~min}$, to $20 \% \mathrm{~A}$ at $53 \mathrm{~min}$, then from 20 to $96 \% \mathrm{~A}$ at $54 \mathrm{~min}$, and maintaining $96 \%$ A for $11 \mathrm{~min}$ (65 min). The flow rate was $0.8 \mathrm{~mL} / \mathrm{min}$ and the injection volume was $20 \mu \mathrm{L}$. The detection of phenolic acids, flavonoids, and resveratrol was carried out at $280 \mathrm{~nm}$ on the column maintained at $25^{\circ} \mathrm{C}$. The separated peaks were identified by comparing their 
retention times with those acquired for corresponding standards, while quantification was performed using external calibration curves generated for each detected compound. Additionally, sample spiking was also used to assist confirmation of peak identity.

The anthocyanins were detected at $520 \mathrm{~nm}$ on the column maintained at $40^{\circ} \mathrm{C}$. The elution solvents in this method were $0.3 \%$ perchloric acid in water (solvent A) and $0.3 \%$ perchloric acid in methanol (solvent B). The linear gradient was as follows: from $28 \%$ B to $51 \%$ B in $42 \mathrm{~min}$, then to $69 \%$ in $3 \mathrm{~min}$ and to $80 \% \mathrm{~B}$ in $1 \mathrm{~min} 80 \% \mathrm{~B}$ for $3 \mathrm{~min}$. The time of equilibration for the column to the initial gradient was $6 \mathrm{~min}$. The flow rate was $0.6 \mathrm{~mL} / \mathrm{min}$ and the injection volume was $10 \mu \mathrm{L}$. The peaks of anthocyanins were identified and quantified as described by Vanzo et al. [2008] and Budić-Leto et al. [2018]. The compounds were eluted in order of polarity which was used for their identification (according to the retention time of each peak at $520 \mathrm{~nm}$ ), while quantifications (concentration in $\mathrm{mg} / \mathrm{L}$ ) were performed using the external standard curve generated for malvidin 3-O-glucoside.

\section{Antioxidant activity}

The reducing activity of the samples was detected as the ferric reducing antioxidant power (FRAP) [Benzie \& Strain, 1996] and the results are expressed as micromoles of Trolox equivalents per litre ( $\mu \mathrm{mol} \mathrm{TE} / \mathrm{L})$.

The free radical-scavenging capacity against 2,2-diphenyl-1-picrylhydrazyl radical (DPPH*) was investigated according to the procedure described by Katalinić et al. [2013] and the results are expressed as inhibition percentage (\%).

\section{Statistical analysis}

All analyses were carried out in triplicate and the data are given as the mean \pm standard deviation. Statistical analysis was performed using STATGRAPHICS ${ }^{\circledR}$ Centurion XVI (StatPoint Technologies, Inc., The Plains, Virginia, USA). Differences between the investigated parameters were analysed by one-way ANOVA followed by Fisher's least significant difference test, while Pearson's correlation coefficient $(p<0.05)$ was used to determine relations between the variables.

\section{RESULTS AND DISCUSSION}

Changes in concentrations of total phenolics and anthocyanins in Babica wine sampled during the vinification, with and without enzyme addition, are presented in Figure 1. The phenolics content was continuously increasing during the vinification, with slight decreases between the first and the second racking in the control sample and in the wine produced by the addition of Vinozym Vintage. At the end of winemaking, the highest concentration of phenolics was detected in the sample produced by the addition of Sihazym Extro (1771 mg GAE/L), while the two other wine samples contained the similar amount of phenolic compounds. Figure $1 \mathrm{~b}$ presents results obtained for monomeric anthocyanins content and they are in agreement with those reported in our previous study [Generalić Mekinić et al., 2019]. The majority of anthocyanins were extracted during the first few days of maceration, supporting the results reported by Ivanova et al.
[2012] who demonstrated that extended maceration resulted in a slight decrease in the content of phenolic compounds and anthocyanins. The Vinozyme Vintage sample showed the highest value at day four (180 mg M-3-gl/L) and a slight decrease on the fifth day, while the anthocyanin content of the other two samples increased. Again, a decrease of anthocyanins from the first to the second racking can be noted in all samples with the final concentration being $144 \mathrm{mg}$ $\mathrm{M}-3-\mathrm{gl} / \mathrm{L}$ in the control wine, $142 \mathrm{mg} \mathrm{M}-3-\mathrm{gl} / \mathrm{L}$ in the Vinozyme Vintage sample, and $152 \mathrm{mg} \mathrm{M}-3-\mathrm{gl} / \mathrm{L}$ in the Sihazym Extro sample. Statistical analysis confirmed a high correlation between the phenolic and anthocyanin content $(r=0.9348$, $\mathrm{p}<0.0001$ ). If the results obtained for Babica are compared to those obtained for $C$. kaštelanski, it can be concluded that $C$. kaštelanski contains almost 2-fold higher concentration of total phenolics, while the content of anthocyanins is higher in Babica (especially in the samples prepared with Sihazym Extro). These results could be partially compared to those reported by Maletic et al. [2009] where two close relatives of $C$. kaštelanski (Dobričić and Plavac mali) contained more phenolics than Babica. However, these authors reported a high concentration of anthocyanins in Babica (200 mg/L). The highest concentration of anthocyanins was found in Dobričić while the lowest among all tested cultivars was detected in Crljenak viški $(50.7 \mathrm{mg} / \mathrm{L})$ and Plavac mali $(81.5 \mathrm{mg} / \mathrm{L})$. Results of their study confirmed also a negative correlation between contents of shikimic acid, which is important in the biosynthesis of anthocyanins, and anthocyanins.

The phenolic profiles of the investigated wines are shown in Table 1. Three phenolic acids (gallic, protocatechuic, and $p$-hydroxybenzoic acid), two flavonoids from the group of flavan-3-ols (catechin and its epimer), flavonol quercetin, and stilbene resveratrol were detected in all samples. The gallic acid was dominant among phenolic acids with the concentration range from 16.68 to $17.80 \mathrm{mg} / \mathrm{L}$. The protocatechuic acid content was the highest in the control wine, while enzyme addition enhanced the extraction of $p$-hydroxybenzoic acid. Catechin and epicatechin are the most abundant compounds among the flavan-3-ols, which are usually detected in wines. These compounds are important as they interact with the anthocyanins by the process of co-pigmentation and play a crucial role in defining the sensory properties of red wines. The extraction of these flavan-3-ols is enhanced with prolongation of the maceration process and an increase of ethanol amount [Bautista-Ortin et al., 2007; Katalinić et al., 2004]. From the presented results it can be seen that both enzymes significantly affected extraction of catechin, while Sihazym Extro had a negative effect on epicatechin and quercetin contents. The concentration of resveratrol in the samples ranged from $1.86 \mathrm{mg} / \mathrm{L}$ to $2.82 \mathrm{mg} / \mathrm{L}$ with the maximum concentration found in the Vinozym Vintage wine sample. The detected concentrations of resveratrol are several times higher than those detected in C. kaštelanski wine [Generalić Mekinić et al., 2019].

Furthermore, 16 different anthocyanin derivatives (in the form of 3-O-glucosides, 3-O-acetylglucosides, (6-O-caffeoyl)glucosides, and (6-O-coumaryoyl)glucosides) were detected in the samples and the results are presented in Table 1, while the chromatograms are shown in Figure 2. Grape 
a)

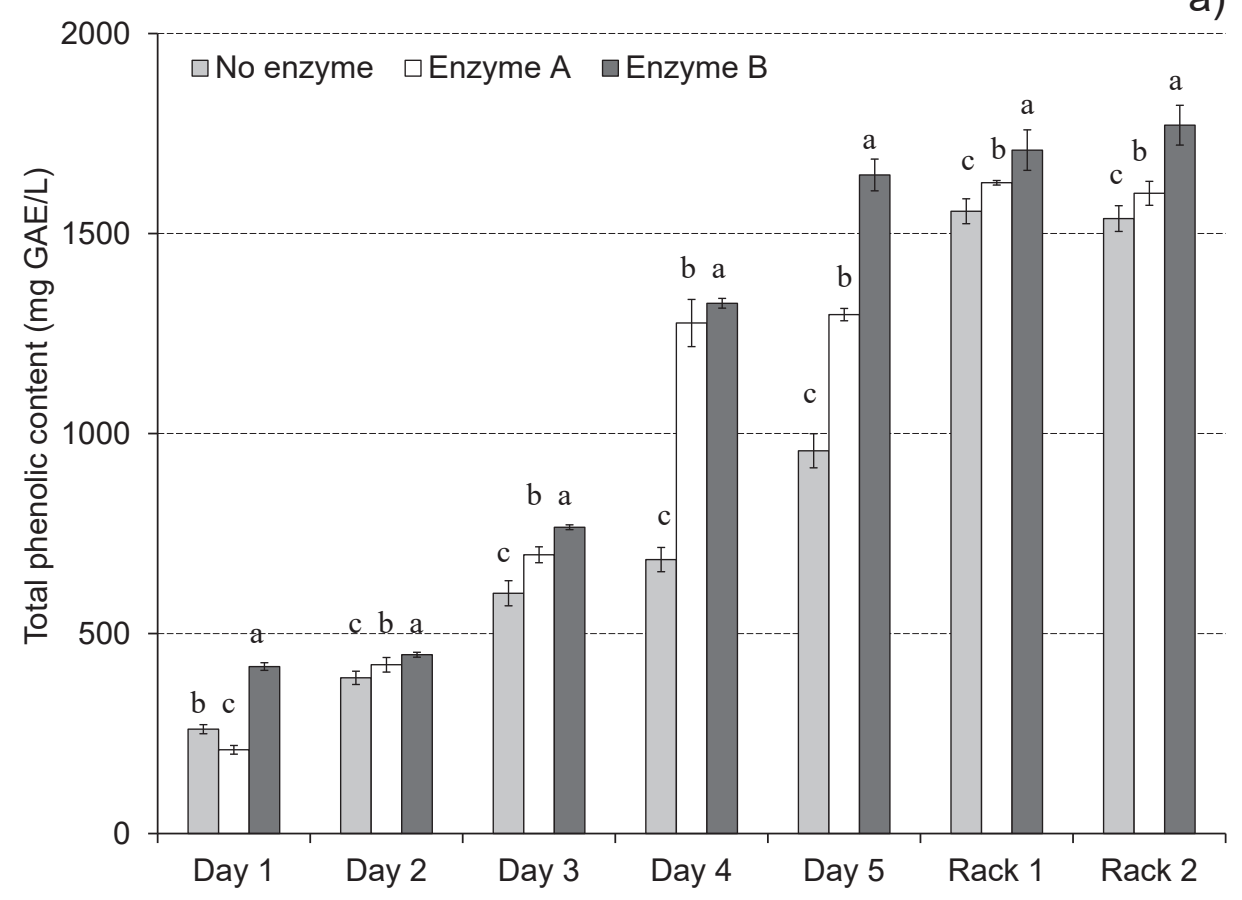

b)

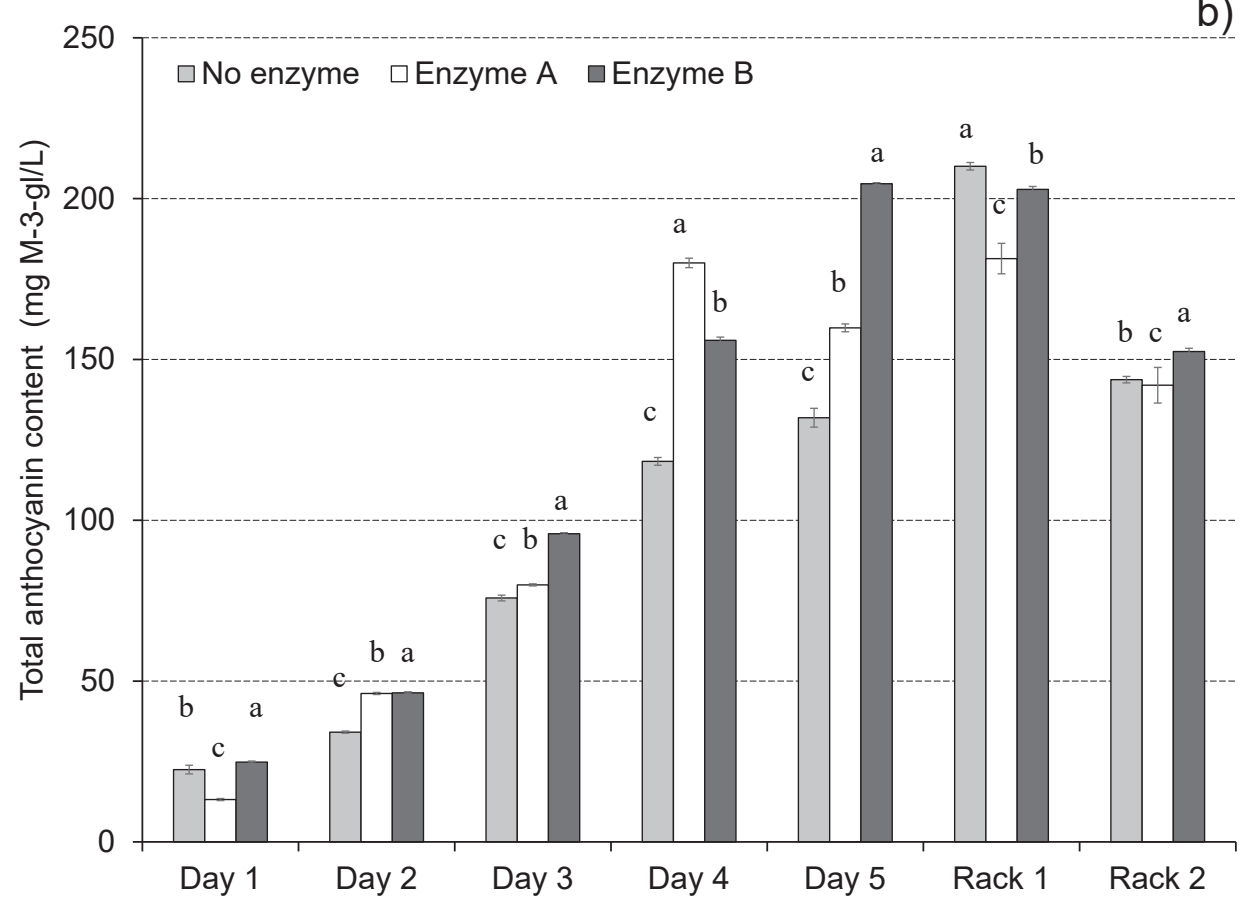

FIGURE 1. Changes of a) total phenolics and b) total anthocyanins in Babica wine during the vinification without enzyme addition and with the addition of enzyme A (Vinozym Vintage) or enzyme B (Sihazym Extro).

GAE- gallic acid equivalents, Enzyme A - Vinozym Vintage, Enzyme B - Sihazym Extro, M-3-gl- malvidin 3-O-glucoside, Rack 1/Rack 2- 40/160 day of winemaking process. Different letters $(\mathrm{a}-\mathrm{c})$ above bars denote statistically significant difference $(\mathrm{p}<0.05)$ among wine samples.

anthocyanidins are usually in the form of glycosides (primarily glucosides) in which the sugar component of the molecule increases their stability and solubility. The major forms of anthocyanins in Babica wine samples were 3-O-glucosides, with malvidin being the dominant and the most stable form. These results are consistent with those obtained in C. kaštelanski
[Generalić Mekinić et al., 2019], but also with other results available in the literature [Alpeza et al., 2017; He et al., 2012; Maletić et al., 2009]. The proportion of malvidin derivatives in total anthocyanins reached $82 \%$ in the control wine and $81 \%$ in the enzyme-treated wines. The content of malvidin-3-O-glucoside after the first racking ranged from 91.62 to 
TABLE 1. Phenolic compounds content of Babica young wine ( $\mathrm{mg} / \mathrm{L}$ ) produced by traditional vinification without and with the addition of enzymes Vinozym Vintage (Enzyme A) or enzyme Sihazym Extro (Enzyme B).

\begin{tabular}{|c|c|c|c|c|}
\hline Group & Phenolic compound & No enzyme & Enzyme A & Enzyme B \\
\hline \multirow{3}{*}{ Phenolic acids } & Gallic acid & $16.68 \pm 0.08^{\mathrm{c}}$ & $17.80 \pm 0.07^{\mathrm{a}}$ & $17.39 \pm 0.23^{\mathrm{b}}$ \\
\hline & Protocatechuic acid & $2.12 \pm 0.03^{\mathrm{a}}$ & $1.89 \pm 0.05^{\mathrm{b}}$ & $1.79 \pm 0.06^{\mathrm{c}}$ \\
\hline & $p$-Hydroxybenzoic acid & $1.48 \pm 0.11^{\mathrm{c}}$ & $2.30 \pm 0.14^{\mathrm{a}}$ & $2.12 \pm 0.05^{\mathrm{b}}$ \\
\hline \multirow{3}{*}{ Flavonoids } & Catechin & $31.79 \pm 0.22^{\mathrm{c}}$ & $44.34 \pm 0.25^{\mathrm{a}}$ & $42.27 \pm 0.38^{\mathrm{b}}$ \\
\hline & Epicatechin & $62.02 \pm 1.01^{\mathrm{b}}$ & $65.10 \pm 2.23^{\mathrm{a}}$ & $38.46 \pm 0.53^{c}$ \\
\hline & Quercetin & $1.39 \pm 0.02^{\mathrm{b}}$ & $1.65 \pm 0.02^{\mathrm{a}}$ & $1.24 \pm 0.02^{\mathrm{c}}$ \\
\hline \multirow[t]{8}{*}{ Stilbenes } & Resveratrol & $1.86 \pm 0.01^{\mathrm{c}}$ & $2.82 \pm 0.04^{\mathrm{a}}$ & $2.17 \pm 0.02^{\mathrm{b}}$ \\
\hline & Delphinidin-3-O-glucoside & $3.27 \pm 0.01^{\mathrm{a}}$ & $3.22 \pm 0.02^{\mathrm{b}}$ & $2.66 \pm 0.04$ \\
\hline & Cyanidin-3-O-glucoside & $0.14 \pm 0.01^{\mathrm{a}}$ & $0.15 \pm 0.01^{\mathrm{a}}$ & $0.15 \pm 0.02^{a}$ \\
\hline & Petunidin-3-O-glucoside & $6.15 \pm 0.13^{\mathrm{a}}$ & $6.30 \pm 0.36^{\mathrm{a}}$ & $6.13 \pm 0.62^{\mathrm{a}}$ \\
\hline & Peonidin-3-O-glucoside & $4.04 \pm 0.37^{\mathrm{b}}$ & $4.27 \pm 0.17^{\mathrm{ab}}$ & $4.47 \pm 0.21^{\mathrm{a}}$ \\
\hline & Malvidin-3-O-glucoside & $59.90 \pm 0.25^{b}$ & $58.86 \pm 0.02^{\mathrm{c}}$ & $61.91 \pm 0.20^{\mathrm{a}}$ \\
\hline & Delphinidin-3-O-acetylglucoside & $0.82 \pm 0.05^{\mathrm{b}}$ & $0.56 \pm 0.00^{c}$ & $1.10 \pm 0.09^{\mathrm{a}}$ \\
\hline & Cyanidin-3-O-acetylglucoside & $0.03 \pm 0.00^{\mathrm{b}}$ & $0.03 \pm 0.01^{\mathrm{b}}$ & $0.07 \pm 0.00^{\mathrm{a}}$ \\
\hline \multirow{9}{*}{ Anthocyanins } & Petunidin-3-O-acetylglucoside & $0.13 \pm 0.00^{\mathrm{b}}$ & $0.14 \pm 0.01^{\mathrm{a}}$ & $0.10 \pm 0.00^{\circ}$ \\
\hline & Peonidin-3-O-acetylglucoside & $0.25 \pm 0.00^{\mathrm{b}}$ & $0.27 \pm 0.01^{\mathrm{a}}$ & $0.23 \pm 0.00^{\circ}$ \\
\hline & Petunidin-(6-O-caffeoyl)glucoside & $0.11 \pm 0.00^{\mathrm{b}}$ & $0.10 \pm 0.00^{\mathrm{b}}$ & $0.24 \pm 0.07^{a}$ \\
\hline & Malvidin-3-O-acetylglucoside & $2.59 \pm 0.01^{\mathrm{c}}$ & $2.70 \pm 0.02^{\mathrm{b}}$ & $2.90 \pm 0.13^{a}$ \\
\hline & Malvidin-(6-O-caffeoyl)glucoside & $1.16 \pm 0.02^{\mathrm{a}}$ & $0.91 \pm 0.02^{\mathrm{c}}$ & $0.98 \pm 0.01^{\mathrm{b}}$ \\
\hline & Cyanidin-(6-O-coumaryoyl)glucoside & $0.27 \pm 0.00^{\mathrm{b}}$ & $0.30 \pm 0.00^{\mathrm{a}}$ & $0.20 \pm 0.00^{c}$ \\
\hline & Petunidin-(6-O-coumaryoyl)glucoside & $0.04 \pm 0.00^{\mathrm{b}}$ & $0.05 \pm 0.00^{\mathrm{b}}$ & $0.06 \pm 0.00^{\mathrm{a}}$ \\
\hline & Peonidin-3-(6-O-coumaroyl)glucoside & $0.58 \pm 0.00^{c}$ & $0.72 \pm 0.02^{\mathrm{a}}$ & $0.65 \pm 0.01^{\mathrm{b}}$ \\
\hline & Malvidin-3-(6-O-coumaroyl)glucoside & $4.30 \pm 0.00^{c}$ & $4.82 \pm 0.03^{\mathrm{a}}$ & $4.37 \pm 0.02^{\mathrm{b}}$ \\
\hline
\end{tabular}

Enzyme A - Vinozym Vintage; Enzyme B - Sihazym Extro. Different letters (a-c) in superscript in the row denote statistically significant difference $(\mathrm{p}<0.05)$ between concentrations of detected phenolics in wine samples.

$95.13 \mathrm{mg} / \mathrm{L}$ (data not showed), while at the end of the vinification process those values significantly decreased. A significant correlation was observed between concentrations of malvidin-3-O-glucoside and monomeric anthocyanins $(\mathrm{r}=0.5982, \mathrm{p}=0.0042)$.

The colour of red wine is influenced by numerous wine-growing and processing factors affecting transfer of pigments during wine-making. Moreover, during the maturation and aging, the red wine colour changes from an intense red hue characteristic for anthocyanins to a more red-orange hue which comes from different anthocyanin-derived compounds (pyranoanthocyanins) [He et al., 2012]. Wines with higher co-pigmentation and higher amount of acylated forms of non-malvidin compounds have deeper colour [Boulton, 2001]. Although these colour changes can be observed with the naked eye, they are usually easily determined spectrophotometrically by measuring such parameters as $\mathrm{CI}$ and $\mathrm{T}$, as well as OD 420, OD 520, and OD 620. 


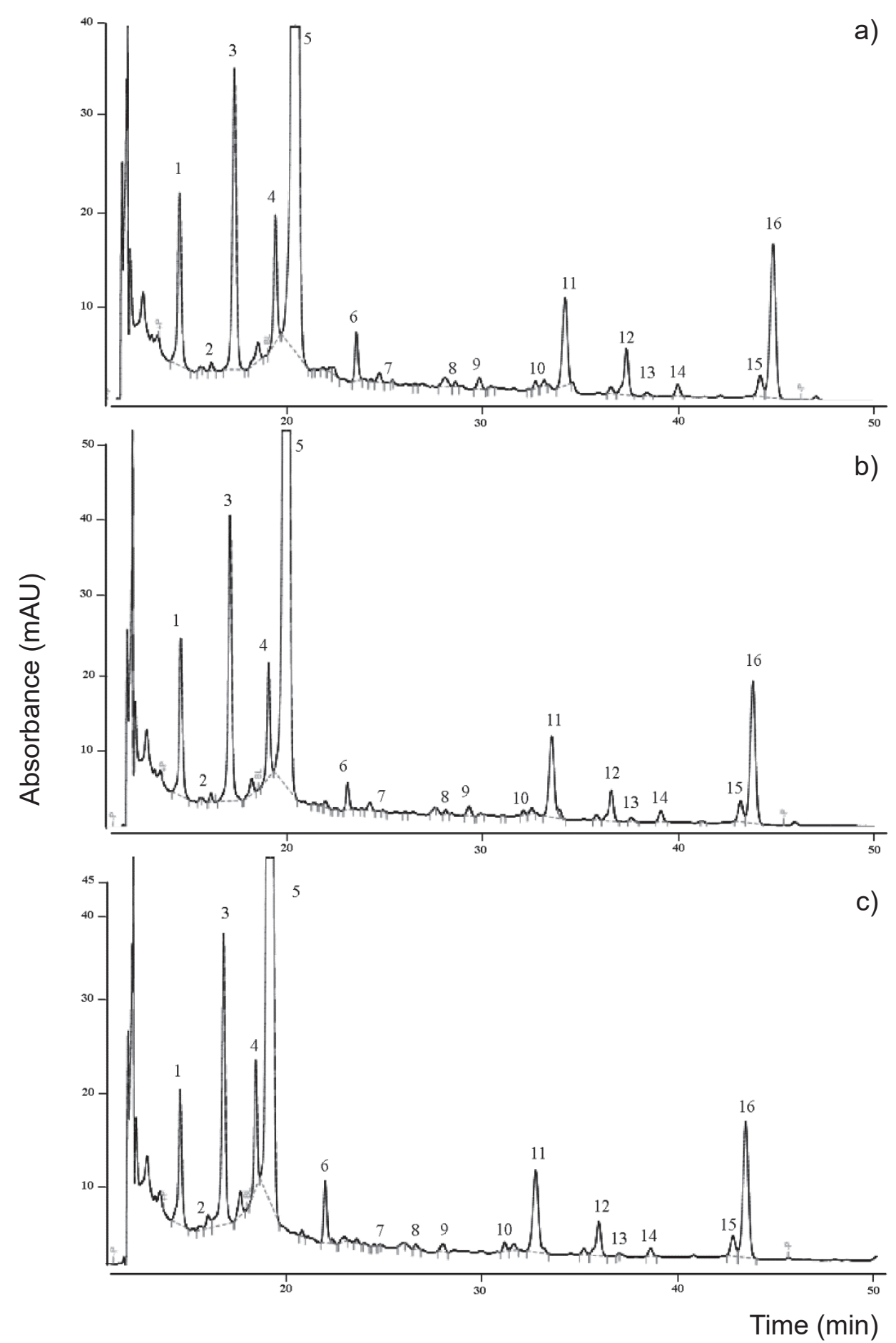

FIGURE 2. HPLC Chromatograms at $520 \mathrm{~nm}$ of Babica wine samples produced: a) without enzyme addition, b) with Vinozyme Vintage, and c) with Sihazym Extro.

Peaks are identified as follows: 1) Delphinidin-3-O-glucoside, 2) Cyanidin-3-O-glucoside, 3) Petunidin-3-O-glucoside, 4) Peonidin-3-O-glucoside, 5) Malvidin-3-O-glucoside, 6) Delphinidin-3-O-acetylglucoside, 7) Cyanidin-3- $O$-acetylglucoside, 8) Petunidin-3- $O$-acetylglucoside, 9) Peonidin-3- $O$ -acetylglucoside, 10) Petunidin-(6-O-caffeoyl)glucoside, 11) Malvidin-3-O-acetylglucoside, 12) Delphinidin-(6-O-caffeoyl)glucoside, 13) Cyanidin-(6-O-coumaryoyl)glucoside, 14) Petunidin-(6-O-coumaryoyl)glucoside, 15) Peonidin-3-(6-O-coumaroyl)glucoside, and 16) Malvidin-3-(6-O-coumaroyl) glucoside.

$\mathrm{CI}$, usually defined as the colour amount that indicates wine darkness, is a parameter that is mostly determined by the content and structure of the anthocyanins present in wine [Glories, 1984]. The CI of Babica wines was successively increasing and the highest values were detected in all samples after the second racking (Figure 3). Ivanova et al. [2012] investigated the effect of the maceration on the extraction of wine colour components and found a correlation between the concentration of total anthocyanins and the CI. In this study, a correlation was also detected between the value of this pa- 

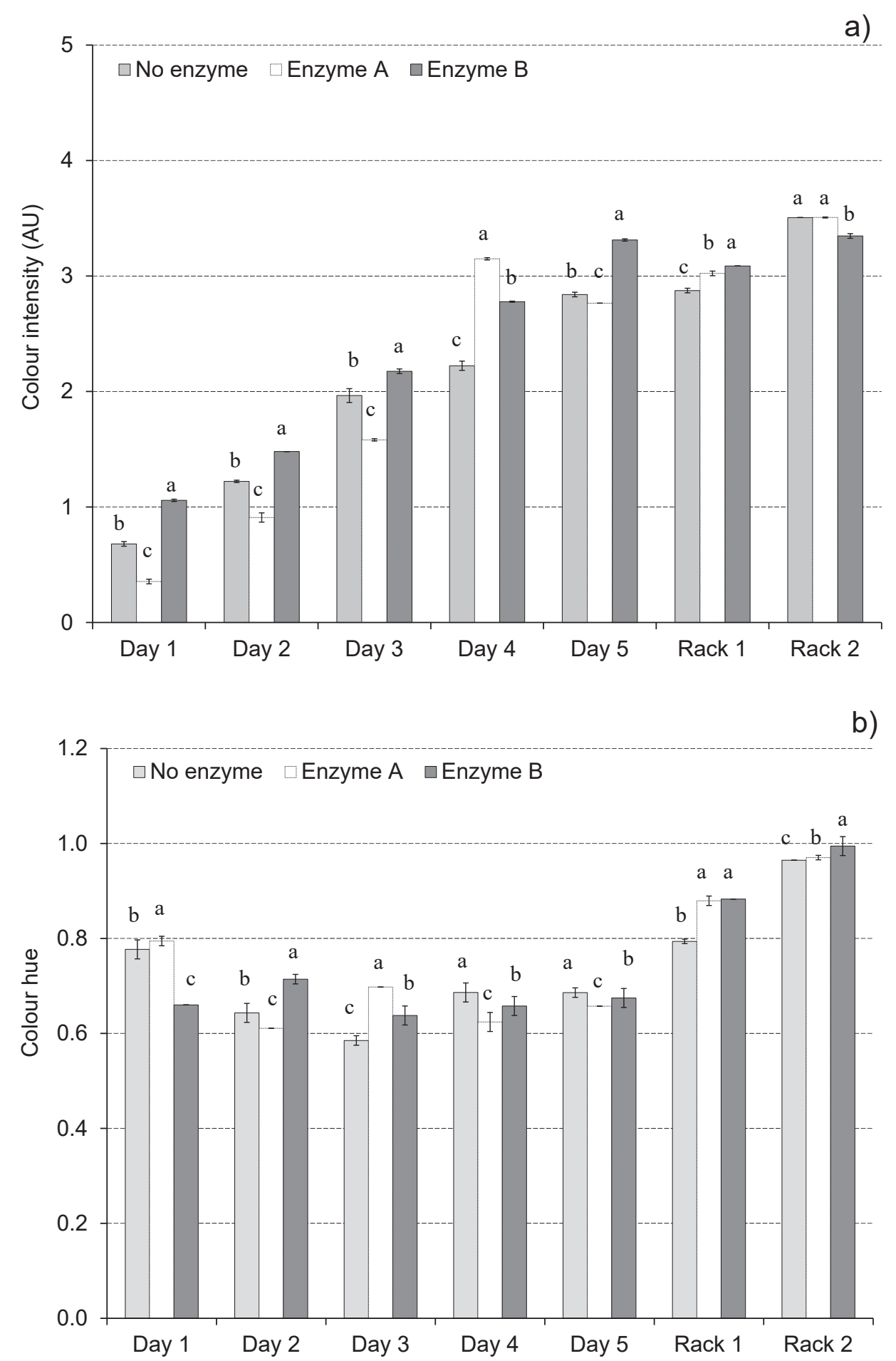

FIGURE 3. Colour parameters: a) colour intensity (CI) and b) colour hue (T) of Babica wine produced by traditional vinification and by the addition of enzymes.

Rack 1/Rack 2- 40/160 day of winemaking process. Different letters (a-c) above bars denote statistically significant difference $(\mathrm{p}<0.05)$ among wine samples.

rameter and total phenolics content $(\mathrm{r}=0.9416, \mathrm{p}<0.0001)$ as well as between $\mathrm{CI}$ and monomeric anthocyanins content $(\mathrm{r}=0.9150, \mathrm{p}<0.0001)$. $\mathrm{T}$ is a parameter that indicates the development of a colour towards orange tones and it increases during wine aging. Its highest values were recorded after the second racking (range from 0.96 to 0.99). Ribéreau-Gayon et al. [2006] reported that the normal T values for young red wines are between 0.5 and 0.7 but they increase during wine ageing up to 1.3. Figure 4 shows the shares of the three basic colour components (yellow, red and blue) in the overall Babica wine colour during the vinification without and with enzyme addition. The highest absorption was detected at the wavelength of $520 \mathrm{~nm}$ where red wines have the maximal absorption. According to Glories [1984], the most optimal ra- 

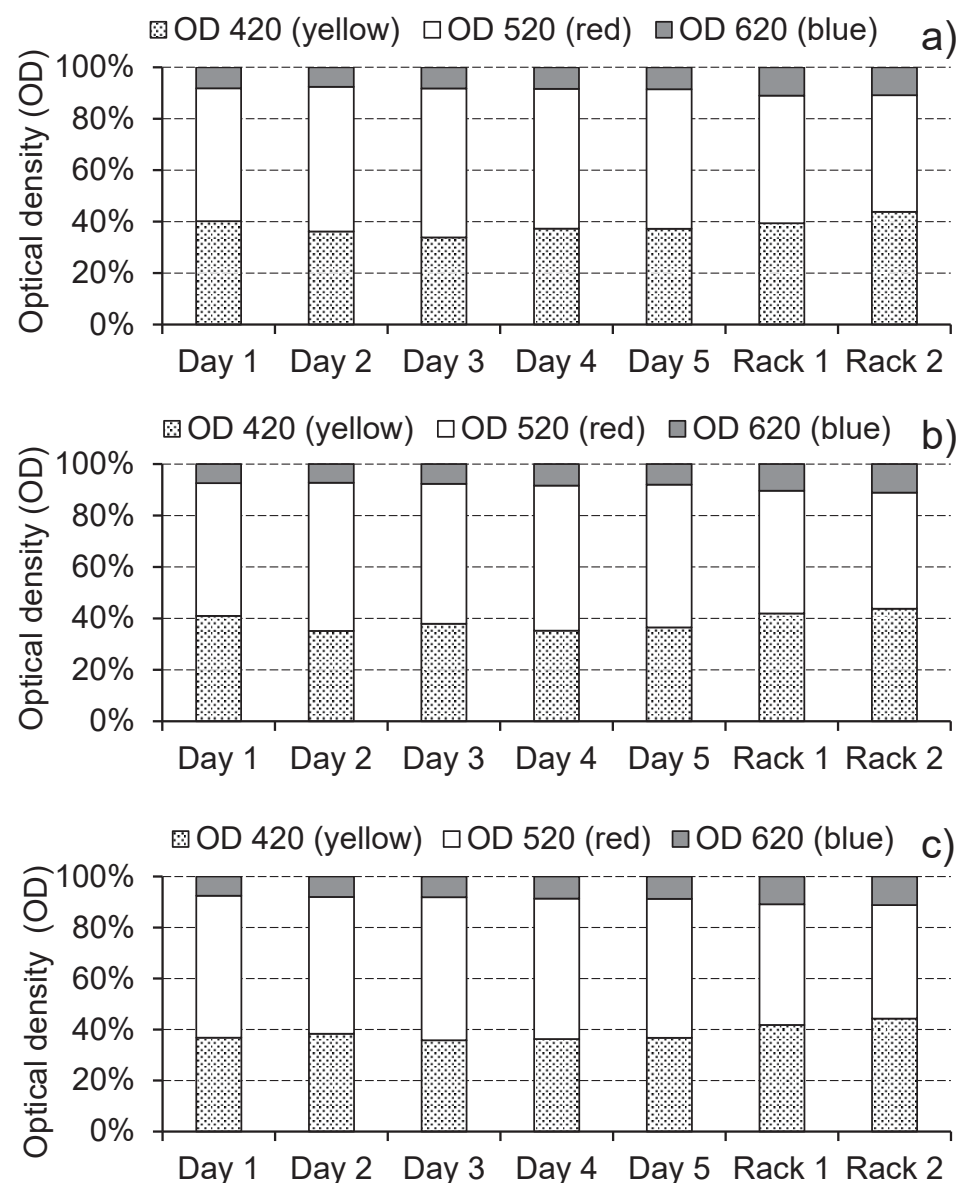

FIGURE 4. Colour composition of the three basic colour components in Babica wine during the vinification without enzyme addition (a) and with Vinozyme Vintage (b) and Sihazym Extro. Rack 1/Rack 2- 40/160 day of winemaking process.

tio of these three basic colour components in the overall wine colour is $35 \%$ of yellow, $55 \%$ of red and $10 \%$ of blue. Results presented in Figure 2. are in accordance with those optimal values as OD 520 ranged from $51.61 \%$ to $57.89 \%$ for all three samples and the maximal value was measured at the third day of maceration in the control sample. After that, these values decreased and after the second racking they were around $45 \%$, the OD 420 was around 44\% while OD 620 was around $11 \%$.

Comparison of the antioxidant properties of Babica wine samples collected during the vinification with and without enzymes is shown in Figure 5. Two different methods were applied to get an insight into the antioxidant properties of the investigated wines during vinification, i.e. free radical scavenging ability using DPPH radical and reducing power assay by FRAP method. DPPH radical has been widely used for the determination of the antioxidant properties and the method is based on hydrogen atom transfer mechanism; while FRAP assay represents a method based on electron transfer reactions [Skroza et al., 2015]. A continuous growth of antioxidant properties during the vinification can be noted for the control wine and the wine produced by the addition of Sihazyme Extro, while a slight decrease of these parameters from the racking 1 to racking 2 has been detected for the Vinozym Vintage wine. However, the final results point out a good antioxidant activity of all samples, with the Sihazyme Extro wine being the most potent (FRAP value of $6763 \mu \mathrm{mol}$ TE/L, DPPH in- hibition of $24.4 \%)$. The total phenolics content showed a significant correlation with FRAP values $(r=0.9957, p<0.0001)$ as well as with DPPH inhibition $(r=0.9642, p<0.0001)$. Also, correlations were found between anthocyanins/malvidin 3-O-glucoside and FRAP $(\mathrm{r}=0.9124, \mathrm{p}<0.0001 / \mathrm{r}=0.7585$, $\mathrm{p}=0.0001)$ and between anthocyanins/malvidin 3-O-glucoside and DPPH $(r=0.9154, p<0.0001 / r=0.7120, p=0.0003)$.

\section{CONCLUSION}

The use of pectolytic enzyme preparations in winemaking is a well-established practice for improving wine quantity and quality. The results of this study contribute to a better understanding of the mechanism of enzyme actions and their effect on the phenolic profile, chromatic characteristics, and antioxidant properties of wine. Although there were differences in the extraction kinetic of phenolics between the control and the enzyme-treated wines, the use of enzymes, especially Sihazym Extro, improved the extraction of phenolics and anthocyanins. Wine colour properties, especially CI, correlated with the phenolics content and profile. Furthermore, all samples showed an increasing antioxidant activity during the vinification, with Sihazym Extro sample being the most potent. The results contribute to the general knowledge on the applied oenological practice for the production of highly coloured wines with the added health-promoting properties. 
a)

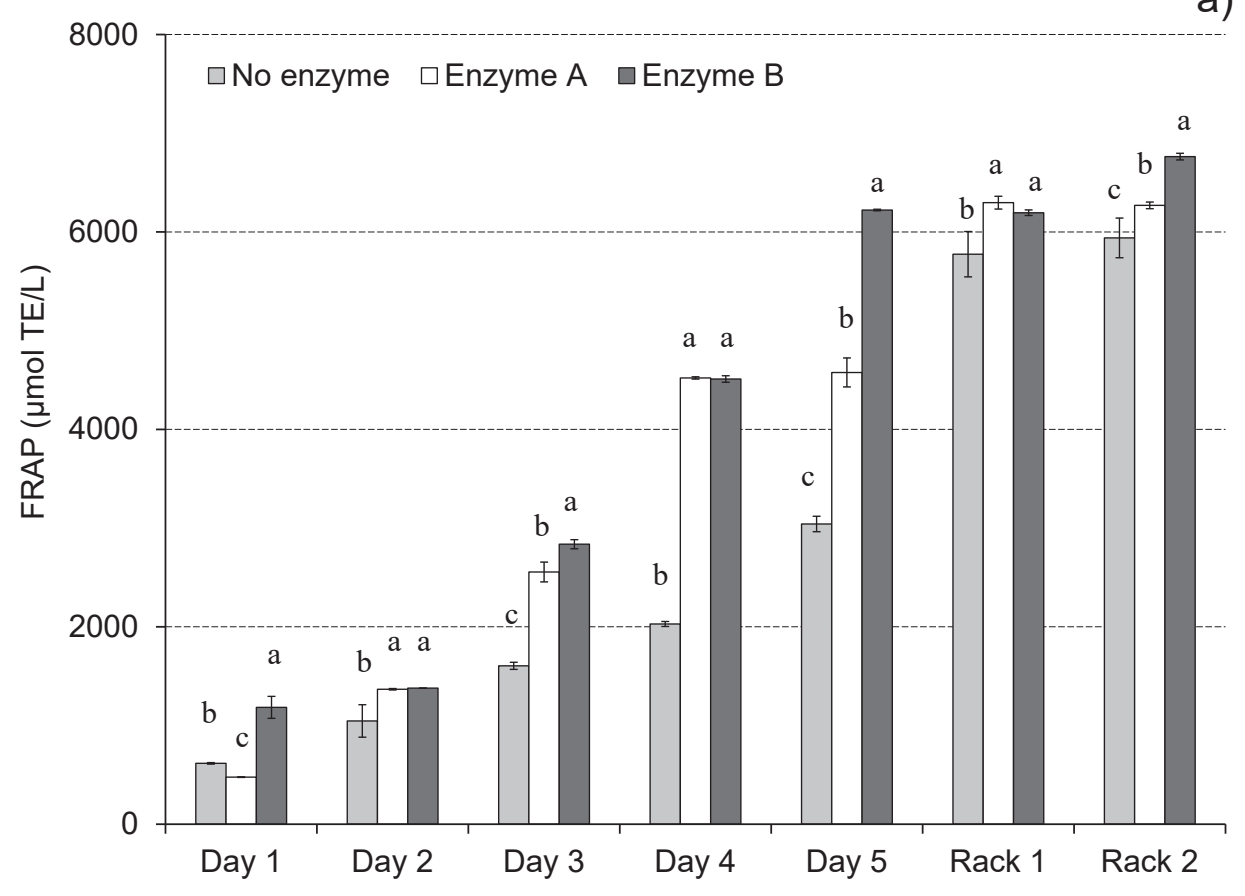

b)

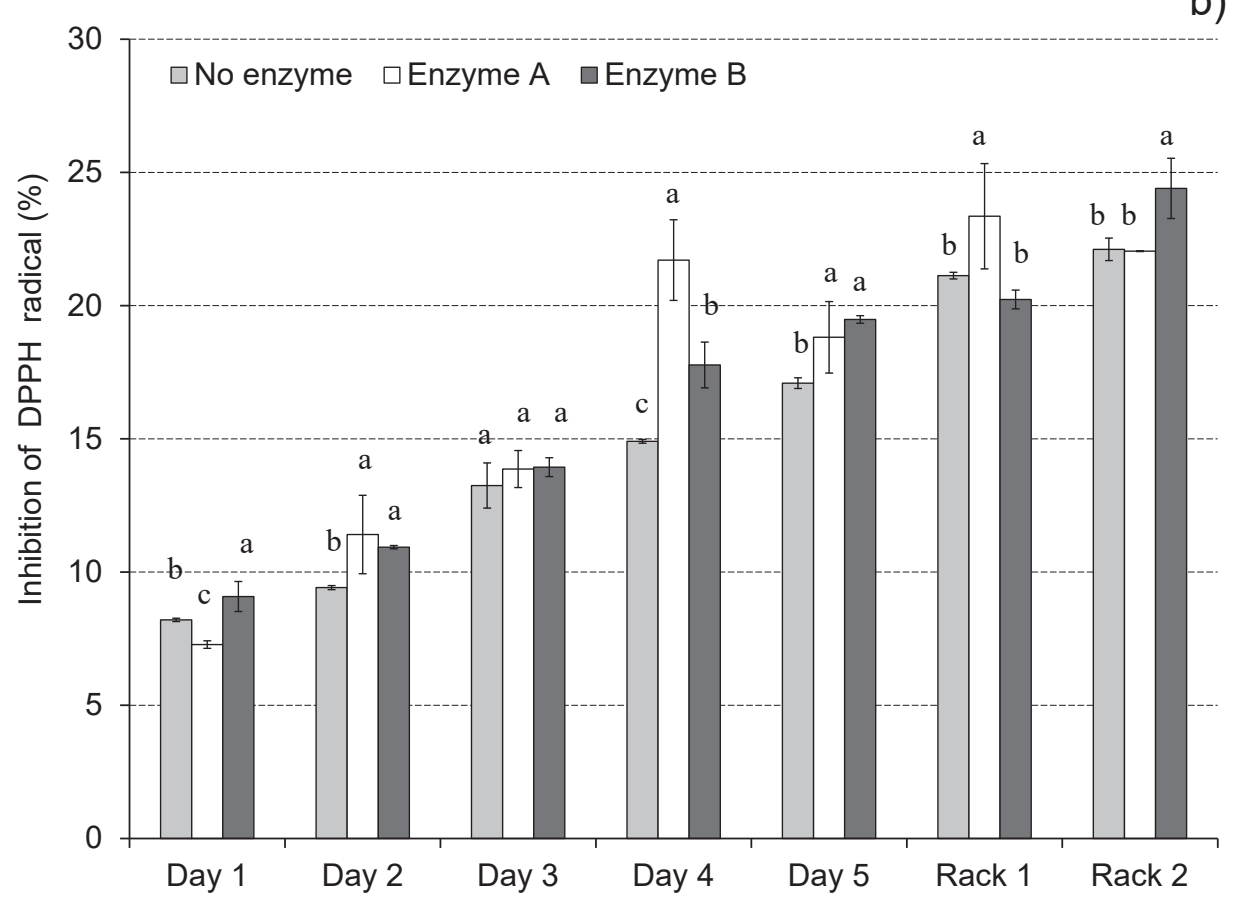

FIGURE 5. Comparison of the antioxidant properties of Babica wine samples with and without enzymes during vinification obtained by FRAP (a) and DPPH (b) method.

Enzyme A - Vinozym Vintage, Enzyme B - Sihazym Extro, TE- Trolox equivalents. Rack 1/Rack 2- 40/160 day of winemaking process. Different letters $(a-c)$ above bars denote statistically significant difference $(p<0.05)$ among wine samples. 


\section{RESEARCH FUNDING}

This work has been partially supported by Croatian Science Foundation under the project IP-2013-11-8652.

\section{CONFLICT OF INTERESTS}

Authors declare no conflict of interests.

\section{REFERENCES}

1. Alpeza, I., Kovačević Ganić, K., Vanzo, A., Herjavec, S. (2017). Improved chromatic and sensory characteristics of Plavac mali wines - efficiency of maceration enzymes. Czech Journal of Food Sciences, 35(3), 236-245.

2. Amerine, M.A., Ough, C.S. (1980). Methods for Analysis of Musts and Wines. 2nd ed. New York: John Wiley \& Sons, pp. 181-200.

3. Bautista-Ortín, A.B., Fernández-Fernández, J.I., López-Roca, J.M., Gómez-Plaza, E. (2007). The effects of enological practices in anthocyanins, phenolic compounds and wine colour and their dependence on grape characteristics. Journal of Food Composition and Analysis, 20(7), 546-552.

4. Bautista-Ortín, A.B., Martínez-Cutillas, A., Ros-García, J., López-Roca, J.M., Gómez-Plaza, E. (2005). Improving colour extraction and stability in red wines: the use of maceration enzymes and enological tannins. International Journal of Food Science and Technology, 40(8), 867-878.

5. Benzie, I.F.F., Strain, J.J. (1996). The ferric reducing ability of plasma (FRAP) as measurement of "antioxidant power": The FRAP assay. Analytical Biochemistry, 239(1), 70-76.

6. Bichescu, C., Bahrim, G., Stănciuc, N., Râpeanu, G. (2012). Color enhancement of Fetească neagră wines by using pectolytic enzymes during maceration. The Annals of the University Dunarea de Jos of Galati, Fascicle VI - Food Technology, 36(1), 18-25.

7. Boulton, R. (2001). The copigmentation of anthocyanins and its role in the colour of red wine: a critical review. American Journal of Enology and Viticulture, 52(2), 67-87.

8. Budić-Leto, I., Mucalo, A., Ljubenkov, I., Zdunić, G. (2018). Anthocyanin profile of wild grape Vitis vinifera in the eastern Adriatic region. Scientia Horticulturae, 238, 32-37.

9. Claus, H., Mojsov, K. (2018). Enzymes for wine fermentation: current and perspective applications. Fermentation - Basel, 4(3), art. no. 52.

10. El Darra, N.E., Turk, M.F., Ducasse, M.A., Grimi, N., Maroun, R.G., Louka, N., Vorobiev, E. (2016) Changes in polyphenol profiles and colour composition of freshly fermented model wine due to pulsed electric field, enzymes and thermovinification pretreatments. Food Chemistry, 194, 944-950.

11. Generalić Mekinić, I., Skračić, Ž., Kokeza, A., Soldo, B., Ljubenkov, I., Banović, M., Skroza, D. (2019). Effect of winemaking on phenolic profile, colour components and antioxidants in Crljenak kaštelanski (sin. Zinfandel, Primitivo, Tribidrag) wine. Journal of Food Science and Technology, 56(4), 1841-1853.

12. Glories, Y. (1984). La couleur des vins rouges. 2e partie: mesure, origine et interpretation. Journal International des Sciences de la Vigne et du Vin, 18, 253-271 (in French).

13. He, F., Liang, N.N., Mu, L., Pan, Q.H., Wang, J., Reeves, M.J., Duan, C.Q. (2012). Anthocyanins and their variation in red wines II. Anthocyanin derived pigments and their colour evolution. Molecules, 17(2), 1483-1519.

14. Ivanova, V., Vojnoski, B., Stefova, M. (2012). Effect of winemaking treatment and wine aging on phenolic content in Vranec wines. Journal of Food Science and Technology, 49(2), 161-172.

15. Katalinić, V., Milos, M., Modun, D., Musić, I., Boban, M. (2004). Antioxidant effectiveness of selected wines in comparison with (+)-catechin. Food Chemistry, 86(4), 593-600.

16. Katalinić, V., Smole Možina, S., Generalić, I., Skroza, D., Ljubenkov, I., Klančnik, A. (2013). Phenolic profile, antioxidant capacity and antimicrobial activity of crude leaf extracts of six Vitis vinifera L. varieties. International Journal of Food Properties, 16(1), 45-60.

17. Kelebek, H., Canbas, A., Cabaroglu, T., Selli, S. (2007). Improvement of anthocyanin content in the cv. Öküzgözü wines by using pectolytic enzymes. Food Chemistry, 105(1), 334-339.

18. Maletić, E., Kontić, J.K., Preiner, D., Jeromel, A., Patz, C.D., Dietrich, H. (2009). Anthocyanin profile and antioxidative capacity of some autochthonous Croatian red wines. Journal of Food, $\mathrm{Ag}$ riculture and Environment, 7(1), 48-51.

19. Maletić, E., Pejić, I., Karoglan Kontić, J., Zdunić, G., Preiner, D., Šimon, S., Andabaka, Ž., Žulj Mihaljević, M., Bubola, M., Marković, Z., Stupić, D., Mucalo, A. (2015). Ampelographic and genetic characterization of Croatian grapevine varieties. $\mathrm{Vi}$ tis, 54, SI, 93-98.

20. Marquez, A., Dueñas, M., Serratosa, M.P., Merida, J. (2013). Identification by HPLC-MS of anthocyanin derivatives in raisins. Journal of Chemistry, 2013, art. no. 274893.

21. Mihnea, M., González-San José, M.L., Ortega-Heras, M., Pérez-Magariño, S. (2015). A comparative study of the volatile content of Mencía wines obtained using different prefermentative maceration techniques. LWT - Food Science and Technology, 64(1), 32-41.

22. Mojsov, K. (2013). Use of enzymes in wine making: A review. International Journal of Marketing and Technology, 3(9), 112-127.

23. Ortega-Regules, A., Romero-Cascales, I., Ros-García, J.M., López-Roca, J.M., Gómez-Plaza, E. (2006). A first approach towards the relationship between grape skin cell-wall composition and anthocyanin extractability. Analytica Chimica Acta, 563(1-2), 26-32.

24. Ozimec, R., Karoglan Kontić, J., Maletić, M., Matotan, Z., Strikić, F. (2015). Tradicijske sorte i pasmine Dalmacije. Program Ujedinjenih naroda za razvoj, Tiskara Zelina d.d., 142-154 (in Croatian).

25. Pardo, F., Salinas, M.R., Alonso, G.L., Navarr, G., Huerta, M.D. (1999). Effect of diverse enzyme preparations on the extraction and evolution of phenolic compounds in red wines. Food Chemistry, 67(2), 135-142.

26. Ribéreau-Gayon, P., Glories, Y., Maujean, A., Dubourdieu, D., Donèche, B. (2006). Handbook of Enology, Volume 2, The Chemistry of Wine, Stabilization and Treatments. 2nd ed. Wiley, Chichester, pp. 178-181.

27. Río Segade, S., Pace, C., Torchio, F., Giacosa, S., Gerbi, V., Rolle, L. (2015). Impact of maceration enzymes on skin softening and relationship with anthocyanin extraction in wine grapes with different anthocyanin profiles. Food Research International, 71, 50-57.

28. Romero-Cascales, I., Ros-García, J.M., López-Roca, J.M., Gómez-Plaza, E. (2012). The effect of a commercial pectolytic 
enzyme on grape skin cell wall degradation and colour evolution during the maceration process. Food Chemistry, 130(3), 626-631.

29. Sacchi K.L., Bisson, L.F., Adams, D.O. (2005). A review of the effect of winemaking techniques on phenolic extraction in red wines. American Journal of Enology and Viticulture, 56(3), 197-206.

30. Singleton, V.L., Rossi, J. (1965). Colourimetry of total phenolics with phosphomolybdic-phosphotungstic acid reagents. American Journal of Enology and Viticulture, 16, 144-158.

31. Skroza, D., Generalić Mekinić, I., Svilović, S., Šimat, V., Katalinić, V. (2015). Investigation of the potential synergistic effect of resveratrol with other phenolic compounds: A case of binary phenolic mixtures. Journal of Food Composition and Analysis, 38, 13-18.

32. Soto Vázquez, E., Río Segade, S., Orriols Fernández, I. (2010). Effect of the winemaking technique on phenolic composition and chromatic characteristics in young red wines. European Food Research Technology, 231 (5), 789-802.

33. Vanzo, A., Terdoslavich, M., Brandoni, A., Torres, A.M., Vrhovsek, U., Passamonti, S., (2008). Uptake of grape anthocyanins into the rat kidney and the involvement of bilitranslocase. Molecular Nutrition \& Food Research, 52(10), 1106-1116.

34. Zdunić, G., Pejić, I., Karoglan Kontić, J., Vukičević, D., Vokurka, A., Pezo, I., Maletić, E. (2008). Comparison of genetic and morphological data for inferring similarity among native Dalmatian (Croatia) grapevine cultivars (Vitis vinifera L.). Journal of Food, Agriculture and Environment, 6(2), 333-336.

Submitted: 12 July 2019. Revised: 9 September, 15 November, and 2 December 2019. Accepted: 18 December 2019. Published on-line: 30 January 2020. 